\title{
Andalusi Adab in the Mamluk Period
}

\author{
Iria Santás de Arcos
}

\section{Introduction*}

We currently know a lot about the enormous cultural transfer from the Islamic East that reached al-Andalus, particularly in the course of the $3^{\text {th }} / 9^{\text {th }}$ century when Andalusi scholars started to visit the main Eastern centers of knowledge, resulting, as Isabel Toral-Niehoff stated, in "a creative incorporation of knowledge, textual material, cultural models and attitudes of Abbasid Baghdad in Umayyad Córdoba."1 We know less about the reception process, influence, and impact in the Islamic East of the vast amount of knowledge produced in alAndalus, particularly when it comes to works belonging to the literary genre of $a d a b$. Compilations of this genre of $a d a b$, normally thematically arranged and presented in different chapters or books, gathered all the knowledge that an educated man was expected to possess. The first manifestations of this type of Arabic prose writing corresponded to the 8th century and happened especially in the Islamic East. Adab, however, reached a Golden Age during the 9th and 1oth centuries due to the important work also carried out in alAndalus. $^{2}$

This paper intends to reconstruct the reception process in the Islamic East of the most important $a d a b$ works of al-Andalus. It wishes to do so specifically for al-Iqd al-farid, the excellent adab compilation of the 1oth-century Andalusi

* This work has been carried out within the research project "Local contexts and global dynamics: Al-Andalus and the Maghreb in the Islamic East (АMOI)," funded by the Ministry of Economy of Spain (FFI2O16-78878-R) and codirected by Maribel Fierro (ILC-CSIC) and Mayte Penelas (EEA-CSIC). The aim of my research is to study the reception process, influence, and impact in the East of the most important $a d a b$ works of al-Andalus, such as the Bahjat al-majālis by Ibn 'Abd al-Barr (d. 478/1071), the Hadāiq al-azāhir fi mustahsan al-ajwiba wa-muḍikāt wa-l-hikam wa-l-amthāl wa-l-hikayāt wa-l-nawādir by Abū Bakr b. 'Āṣim (d. 829/ 1426), and more particularly al-Iqd al-farīd of Ibn 'Abd Rabbihi.

1 See Toral-Niehoff, History 78; Ramírez del Río, Orientalización; Chalmeta, Historiografía 353404; Chafic, Introducción 51-7; Marín, Transmisión 87-108; Dū n-Nūn Taha, Importance 3944 .

2 See López, ¿Autor 169-93; Cheikh-Moussa, Considérations 25-62; Sadan, Ornate 339-55; Peña Martín and Vega Martín, El ideal 464-502; Veglison, El collar. 
author Ibn 'Abd Rabbihi (246-328/86o-940). ${ }^{3}$ This adab encyclopedia ${ }^{4}$ was one of the first dated texts produced in al-Andalus that has been preserved, and its full impact inside and outside al-Andalus remains to be investigated. ${ }^{5}$ For this reason, after presenting a brief context for the author and his Iqd alfarìd, we will study the possible ways of transmission of Ibn 'Abd Rabbihi's main work to the Islamic East and its reception and influence in later Eastern adab works. Firstly, we will point out the first Andalusi sources that not only mention but also provide relevant information on Ibn 'Abd Rabbihi and his compilation. Secondly, we will analyze the presence and influence of the Iqd al-farid in important Eastern sources, particularly during the Mamluk period.

\section{$2 \quad$ Al-Iqd al-farid: Authorship and Brief Context}

Al-Iqd al-farìd, "The unique necklace," was composed by the Andalusi author Ibn 'Abd Rabbihi (246-328/86o-940) during the Cordovan Umayyad Caliphate (929-1031) and is one of the earliest and most representative examples of adab compilations. Ibn 'Abd Rabbihi came from a local family of clients (mawali) of the Umayyads. He had a long and successful career at the court of the Caliph 'Abd al-Rahmān III (912-61) ${ }^{6}$ under whose reign he wrote this sophisticated and well-organized $a d a b$ compilation.

Al-Iqd al-farid, the only preserved work of the author, was composed with two main purposes: on the one hand, to spread the knowledge produced in the Islamic East in al-Andalus and, in doing so, train officials of the new Umayyad state; and on the other hand, to show the Andalusi literary capacity to the East. With this compendium of $a d a b$, Ibn 'Abd Rabbihi managed to seal the process of "orientalization" in al-Andalus by treating the main historical, philological, and sociological aspects of Arab culture. As a result, his work soon became the most widely read work in al-Andalus. ${ }^{7}$

3 See Brockelmann, Ibn 'Abd Rabbih, 676-7; Ibn Khallikān, Wafayāt 92-4; Werkmeister, Quellenuntersuchungen 42-3; Haremska, Ibn 'Abd Rabbihi i, 620-9; Veglison, El Collar 120-3; Boullata, Unique.

4 For more on the adab genre in al-Andalus, see López ¿Autor 169-93; Soravia, Ibn Qutayba 539-65; Fierro, El saber 83-104.

5 For further information see, for instance, the articles of Toral-Niehoff, Book 134-51; History 61-85. See also Bray, Abassid 1-54; and Kilpatrick, Classical 2-26.

6 For more information about this caliph and the Umayyad Caliphate in al-Andalus, see LéviProvençal and García Gómez España 261-368; Fierro Abd al-Rahman.

7 For an extensive study on this, see Werkmeister, Quellenuntersuchungen; Guillén Monje, Ibn 'Abd Rabbih 306-13. 
The Cordovan author divided his adab anthology into 25 books, and each of them is named after a gem pearl. As a result, the whole multivolume work appears as a perfect necklace of 25 precious pearls of very varied subject matter.

The way Ibn 'Abd Rabbihi chose to compose each book is common to other $a d a b$ works; that is, it includes a large volume of $a k h b \bar{a} r$, interspersed with prophetic traditions (hadiths), Quranic verses, proverbs, and poems. ${ }^{8}$ Despite the fact that this work was composed in the 1oth-century Cordovan Caliphate, most of the akhbār came from Eastern sources, such as the Uyūn al-Akhbār of the 9th-century Iraqi polygraph Ibn Qutayba. And although the Iqd alFarid itself was composed and produced in writing, the reception and circulation of the collected $a k h b \bar{a} r$ would have been carried out in its majority, as Werkmeister states, ${ }^{9}$ by oral transmission.

Whereas the $a k h b \bar{a} r$ he collected were all oriental in origin, throughout the entire work of al-Iqd al-farid Ibn 'Abd Rabbihi enriched all this material with the inclusion of comments, explanations, and criticisms, and with his own verses. Undoubtedly, the most important contribution of the author was his urjüza, a poetic composition in rajaz meter, dedicated to the Caliph 'Abd alRaḥmān III al-Nāṣir, with which he participated, in a significant way, in the legitimation of his caliphate. ${ }^{10}$

The Andalusi author dedicated an important space, particularly in the first books, to what we could call "serious issues," the majority of them abstract concepts such as government, war, power, authorities, or embassies, showing the importance these issues had for Ibn 'Abd Rabbihi. On the contrary, the Andalusi compiler relegated to the last books those subjects he considered less serious and more concrete matters, such as food or jokes. ${ }^{11}$

The Importance of the Iqd in al-Andalus: Andalusi Texts on Ibn 'Abd Rabbihi

Before studying the arrival and the impact of Ibn 'Abd Rabbihi's work in the Islamic East, it is important to introduce the first Andalusi sources that mentioned the author and his adab encyclopedia. Quite soon after his death, later

8 For instance, Ibn 'Abd Rabbihi's main source, the 1oth-century Iraqi adab author Ibn Qutayba, see Ibn Qutayba, 'Uyūn.

9 Werkmeister, Quellenuntersuchungen 46.

10 See Fierro, La legitimidad 147-84; Pompa 125-52; Abderramán; Toral-Niehoff, History 6185; Martínez-Gros, L'idéologie; Monroe, Historical 67-95.

11 See Veglison, El collar; Boullata, Unique. 
Andalusi sources started providing relevant data on Ibn 'Abd Rabbihi and his work, especially between the 11th and 12th centuries. Authors like Ibn alFaraḍi (d. 403/1013) and Ibn Ṣāiid al-Andalusī (d. 462/1069) recorded many fragments of his poetry, calling him "the Andalusi poet" but also praising Ibn 'Abd Rabbihi's skills as an adīb. Thus, Ibn al-Faradī remarked that people from al-Andalus learned not only from Ibn 'Abd Rabbihi's poetry but also from his prose. ${ }^{12}$ Ibn Khāqān (d. 535/1140), for instance, stated:

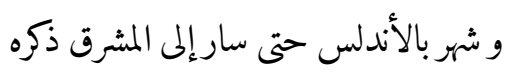

He was very famous in al-Andalus and his fame flew to the East. ${ }^{13}$

He also defended that it was not possible to criticize the Iqd because of its perfect and beautiful Arabic and that due to Ibn 'Abd Rabbihi's talent and literary skills, his fame reached the Islamic East quite soon. But without any doubt, the most important Andalusi author who wrote on Ibn 'Abd Rabbihi was alHumaydī (d. 488/1095), a disciple of Ibn 'Abd al-Barr and Ibn Hazm who left al-Andalus and settled in Baghdad, where he became an important source for the spread of materials dealing with al-Andalus. ${ }^{14}$ In his Jadhwat al-Muqtabis fi ta'rīkh 'ulamā' al-Andalus, al-Humaydī recorded Ibn 'Abd Rabbihi's full biography and much data on his life and his poetry. The information collected by al-Humaydī was used by both Andalusi and Eastern sources in their own works. Among other relevant information, he pointed out that Ibn 'Abd Rabbihi's dīwān, today not preserved, was in Caliph al-Hakam II's library.

Later, in the 13th century, al-Shaqundī wrote his famous risāla in praise of alAndalus named Risāla fifadll al-Andalus, where Ibn 'Abd Rabbihi is mentioned as the greatest author of $a d a b$ in al-Andalus. ${ }^{15}$

\section{Eastern Reception of Ibn 'Abd Rabbihis's al-Iqd al-farìd}

Although it is not easy to specify the exact date that Ibn 'Abd Rabbihi's work became known in the East, we will try to give an approximate answer to the following questions: How and when did Ibn 'Abd Rabbihi's work become known

\footnotetext{
12 Ibn al-Faradi, Tärīkh 81.

13 Ibn Khāqān, Matmah 270.

14 Al-Humaydī, Jadhwat 151.

15 See the study and Spanish translation made by García Gómez, Andalucía contra Berbería, $43^{-141 .}$
} 
in the East? In what way was his work transmitted? And what kind of influence did it have in later Eastern adab compilations? Firstly, it is important to highlight that Ibn 'Abd Rabbihi composed, as he stated in his Iqd, poetry that could be easily remembered so that the $u d a b \bar{a}$ ' and poets from al-Andalus who traveled to the East in search of knowledge (in addition to carrying out their religious obligations) could bring it with them. Against the background of Andalusis' general sense that their merits were not being acknowledged in the East, ${ }^{16}$ this would allow them to prove to the Eastern scholars the literary level that al-Andalus had achieved:

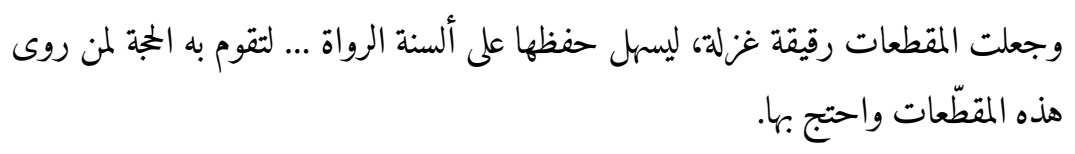

And I made sweet and delicate poems in order to facilitate their memorization to the poets ... to bring it as a sample to whom transmits these poems and made the pilgrimage with them. ${ }^{17}$

Contrary to other cases, in which the descendants and friends of an Andalusi scholar were instrumental in spreading their work, ${ }^{18}$ in the case of Ibn 'Abd Rabbihi, his offspring does not seem to have played any role in spreading Ibn 'Abd Rabbihi's Iqd. He never left al-Andalus, and neither did his nephew, the physician Abū 'Uthmān b. 'Abd Rabbihi (d. 342/953 or 356/966-7). A scholar from the 12th century named Muhammad b. 'Abd Rabbihi al-Hafïd'9 is considered a descendant of Ibn 'Abd Rabbihi but does not quote his ancestor in his Kitāb al-Istibsār. ${ }^{20}$ A disciple named al-Aydī is also known, but no information is extant about how he may have transmitted his teacher's work. ${ }^{21}$ The most reliable hypothesis, therefore, is that it was through Andalusi travelers to the East, not directly related to Ibn 'Abd Rabbihi, that his work traveled outside al-Andalus.

16 For instance, the Buyid vizier al-Ṣāhib b. 'Abbād (326-85/938-95) remarked that the Iqd of Ibn 'Abd Rabbihi was only "our merchandise brought back to us." See Yāqūt al-Ḥamawī, Irshād, i, 463 .

17 Ibn 'Abd Rabbihi, al-Iqd, vii, 270.

18 See, for instance, in this volume, the article of Víctor de Castro about the diffusion of Ibn al-Khațīb's work through his intellectual network. See also Fromherz, Ibn Khaldūn 288305; Molina, The reception 663-80.

19 Puerta Vílchez and Rodríguez Figueroa, Ibn 'Abd Rabbihi 6o9-19.

20 Ibid. 614-18; Ibn Sharīfa, Ibn Abd Rabbihi.

21 Al-Faraḍī, Tảīikh i, 82. 
Regarding the moment when the reception of the work took place, we know that only a few decades after Ibn 'Abd Rabbihi's death, an anthologist from Nishapur in the East, al-Tha'ālibī ${ }^{22}$ (d. 429/1039) quoted in his geographically arranged literary compilation Yatimat al-dahr a substantial amount of material that was taken from Ibn 'Abd Rabbihi's work, especially from his poetry. $\mathrm{He}$ started writing his anthology in 994 to assemble the best literary production until his day, and he included a total of 470 poets and prose writers from different parts of the Islamic world. The fact that Ibn 'Abd Rabbihi was one of these $u d a b \bar{a}$ ' that were mentioned in the Yatima, and the quantity of material al-Thaālibī quoted from him, indicates that the Iqd was already well known in the East at a relatively early stage. ${ }^{23}$

As Bilal Orfali stated in The anthologist's art, orality played a crucial role in the transmission of poetry and $a k h b \bar{a} r$ in al-Tha'ālibỉ's work. Much of the Yatìma's information comes from 1oth-century transmitters al-Tha'ālibì met during their travels or their visits to Nishapur. The majority of these transmitters, as Orfali insists, came from the East and transmitted the poetry and $a k h b \bar{a} r$ of their own regions, as well as that of the regions they visited. The main transmitter of Ibn 'Abd Rabbihi's poetry for the Yatima was an adīb from Nishapur and close friend of al-Tha ālibī named Abu Șāiid 'Abd al-Raḥmān b. Muḥammad b. Dust. ${ }^{24}$ Apparently, the main source of Ibn Dust when transmitting poetry by Ibn 'Abd Rabbihi was the Andalusi faqih al-Walïd b. Bakr who had access both to Ibn 'Abd Rabbihi's Iqd and his dīwān. ${ }^{25}$ The information on Ibn 'Abd Rabbihi is introduced in the Yatima with expressions such as: أنشدت (unshidtu), that is, "it was recited to me," or prefaced with a brief isnād or chain of transmitters. For instance, "(عن/'an) from Muhammad b. Dust, from al-Walīd b. Bakr al-Faqīh al-Andalusî." As it is well known, the Yatima became widely known, and consequently, with its diffusion, the information included on Ibn 'Abd Rabbihi's work also spread. ${ }^{26}$

As for Yāqūt al-Hamawī (d. 626/1229), he states that he received the ijāza (authorization) to transmit the Iqd from Ibn Dihya (d. 633/1235), a famous Maghrebi author, who wrote, for example, a poetic compilation named alMutrib min ash ār ahl al-Maghrib and who settled in the East:

\footnotetext{
22 See Orfali, Anthologist's; Sources 1-47; Works 273-318.

23 See al-Tha'ālibī, Yatīmat ii, 85-144.

24 See Orfali, Sources 45.

25 As noted before, al-Ḥumaydī states that Ibn 'Abd Rabbihi composed a 20 volume dīwān kept in the library of al-Hakam II.

26 See Orfali, Works 273-318.
} 


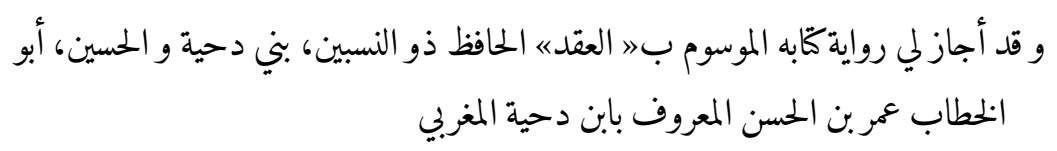

I received the ijāza of his book, known as the "Iqd" from the reciter, owner of two genealogies, Banī Dihya and al-Ḥusayn. Abū l-Khatāb 'Umar b. alHasan, known as Ibn Dihya al-Maghribī. 27

Unfortunately, Ibn 'Abd Rabbihi's Iqd did not make a good impression in other quarters. There is the famous anecdote according to which the Buyid vizier alȘāhib b. 'Abbād (326-85/938-95) remarked when he read the book, "This is our merchandise brought back to us! We do not need it!" This reaction was recorded by Yāqūt in his Irshā $d^{28}$ and confirms that Ibn 'Abd Rabbihi's adab compilation was known in the East very soon, probably even during Ibn 'Abd Rabbihi's lifetime.

In contrast, the risāla of the 1oth-century author al-Ḥasan b. Ahmad alQayrawānī addressed to Abū l-Mughīra b. Ḥazm (a relative of Abū Muhammad b. Hazm, the famous author of the Tawq al-hamama), which was recorded in al-Maqqari's work from the 16th century, insisted on the idea of the good reception that the Iqd received in the East. ${ }^{29}$

\section{Encyclopedism: The Reception Process of Ibn 'Abd Rabbihi's Work during the Mamluk Period}

In the Ayyubid and early Mamluk periods, there was a literary renaissance that has been studied by many scholars, such as Robert Irwin, Th. Emil Homerin, Hilary Kilpatrick, Ulrich Haarmann, and Elias Muhanna, to mention only a few. ${ }^{30}$ Andalusi materials were taken into consideration as by then al-Andalus was associated with poetry (suffice it to mention the impact the muwashshahat had). The presence of many Maghrebi and Andalusi scholars who had settled,

\footnotetext{
27 Yāqūt, Irshād ii, 219-20.

28 Ibid., 214-5.

29 See al-Maqqarī, Naf̣ iv, 138-40.

30 For a general perspective of this period, see Homerin, Reflections 63-85; Franssen, What 311-32; Ghersetti, al-Suyuti; Haarmann, Mamluk 329-47; Irwin, Mamluk 1-29; Kilpatrick, Beyond 71-8o.
} 
especially in Egypt and Syria, also helped in spreading information about the Andalusi literary production. ${ }^{31}$

The Mamluk period was particularly famous for its encyclopedism. The impulse for anthologizing and compiling previous knowledge was carried out not only "because of the writers' fear that all knowledge would be lost as a result of invasions or destruction of libraries,"32 as Elias Muhhanna has remarked in Encyclopaedism in the Mamluk period: The composition of Shihäb al-Dìn alNuwayrī, but also because of the vast amount of literature that circulated. ${ }^{33}$ Scholars began to select and summarize the materials of their predecessors that they considered of great quality or relevance in order to pass it on to future generations. For instance, the Egyptian Ibn Mammātī summarized the anthology al-Dhakhīra fi mahăsin ahl al-jazira (Book of the Treasure-house concerning the elegant aspects of the people of the [Iberian] peninsula) written by the Andalusi author Ibn Bassām al-Shantarinī (d. 543/1147) and named the resulting work Lațäif al-Dhakhïra wa-țarāiq al-jazira, detailing the organization of the Andalusi work. Another important example is that of the distinguished author of the Lisān al-'arab, Ibn Manzūr (d. 711/1311), ${ }^{34}$ who summarized important voluminous compendia written by earlier authors, such as al-Iqd al-farid of Ibn 'Abd Rabbihi. Both cases are evidence that the Andalusi contribution to Arabic literature was known and appreciated by Eastern scholars.

Relevant information is also found in the Ashrafiyya library's catalog that was studied by Konrad Hirschler in his Medieval Damascus: Plurality and diversity in an Arabic library. The Ashrafiyya library catalogue. The Ashrafiyya library, as Konrad Hirschler explains, is an important example of the book revolution initiated in the 9 th and 1oth centuries and of the popularization of libraries in the medieval Middle East. Founded in the 13th century in Damascus by the Ayyubid ruler al-Malik al-Ashraf, the Ashrafiyya library was a minor institution with a remarkable collection of more than 2,00o books, many of them multivolume works composed in the late Ayyubid and early Mamluk periods. Thanks to the preservation of the Ashrafiyya's catalog, we know that one of the books it held was Ibn 'Abd Rabbihi's al-Iqd al-farìd and also the later summary of the Iqd carried out by Ibn Manẓūr. Therefore, contrary to what al-Ṣāhib b.

\footnotetext{
31 See Pouzet, Maghrébins 167-93.

32 As, for instance, happened with the Ayyubid library in the citadel, destroyed by a fire in 1292. Irwin, Mamluk 1-29.

33 See Muhanna, Encyclopaedism.

34 He also epitomizes other earlier voluminous works, such as Ibn 'Asākir's Ta'rīkh Dimashq or Sam‘ānīs Dhayl Ta’rīkh Baghdād. See Brockelmann, Ibn Manẓur, 864.
} 
'Abbād had stated in the 1oth century, three centuries later in the Mashriq, the need for Ibn 'Abd Rabbihi's al-Iqd al-farìd continued to be felt. ${ }^{35}$

In addition to Ibn 'Abd Rabbihi's work, there are other examples of Andalusi adab held in the Ashrafiyya library, for example, the Bahjat al-Majālis by Ibn 'Abd al-Barr and later summaries of the Bahja and the Dhakhïra by Ibn Bassām al-Shantarinī, although it is not clear if the Ashrafiyya also held the summary of this work made by Ibn Mammātī or if the title is mistaken and it is an anonymous collection.

\section{Presence and Influence of Ibn 'Abd Rabbihi's Work in Mamluk Compilations}

Adab compilations are extraordinary examples of the uninterrupted dialogue between oral and written sources and the juxtaposition of prose and poetry. Even though their structure, purpose, and organization differ from one to the other, the common idea was to collect the finest literary material and to preserve and ensure their circulation for future generations.

In the 12th and 13th centuries, adab works gained importance among the Mamluk elite, and this trend continued in later periods. The most popular adab compilation of this time was the Nihāyat al-arabfi funūn al-adab (The ultimate ambition in the branches of erudition) by al-Nuwayrī (667-732/1279-1332). ${ }^{36}$

In his work, al-Nuwayrī relied basically on his contemporary, the Egyptian Muhạmmad b. Ibrāhīm b. Yahyā b. 'Alī al-Anșārī al-Kutubī al-Wațwat (632718/1235-1318), on the tradition of his Eastern forerunners, such as Ibn Qutayba, and also on Andalusi authors whose works served as model examples, such as that of Ibn 'Abd Rabbihi. ${ }^{37}$ Al-Nuwayrì's Nihāyat al-'arab combined prose, verses, or anecdotes. Just as Ibn 'Abd Rabbihi did, it omitted long chains of transmitters so that the reader could focus their attention on the content. The Nihâyat is divided into five books by which the author tried to create a comprehensive guide of the whole universe. In the first three books, the Iqd is one of the sources that was quoted by al-Nuwayri and the Dhakhïra by Ibn Bassām is also used in book one. ${ }^{38}$ The popularity of these Andalusi works is corroborated with quotations included by al-Qalqashandī $\left(75^{-821} / 1355^{-1418}\right)$ in his

35 See Hirschler, Medieval.

36 See Muhanna, World.

37 See al-Nuwayrī's Nihāyat ii, 7-9, 22, 219-2o; iii, 205-6, 219; iv, 2-4; vi, 5-6, 191-2, 211, 222; vii, 8, 186-8; x, 4 .

38 Muhanna, Encyclopaedism 125-8, 180-5. 
Șubh al-Ashhā fì șinā'at al-inshä, considered by Hillary Kilpatrick "more a specialized administration manual than an adab encyclopedia." 39

The texts that undoubtedly require the most attention in this context,

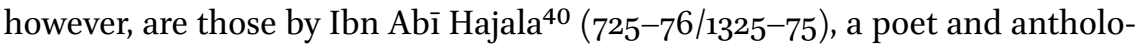
gist born in Tlemcen. In his work, we find evidence of his excellent knowledge of Andalusi literature. For instance, in his Mujtaba $l-u d a b \vec{a}^{\prime}$ (The literatteurs' pick), not preserved but mentioned in his risāla Maghnätis al-durr al-nafiss, he relied on Ibn Bassām's Dhakhira (conceived as a sequel to the Yatīma). Apart from this, in his much admired anthology on profane love, named Dīwān alșabāba, Ibn Abī Hajala included poetry on this subject written by Ibn 'Abd Rabbihi. ${ }^{41}$ In his compilation Salwat al-hazin fi mawt al-banin, dealing with those who suffer the loss of a child, he added Ibn 'Abd Rabbihi's verses dedicated to his deceased son, for instance:

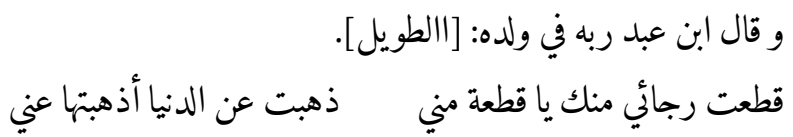

And Ibn 'Abd Rabbihi said about his son:

I lost my hope, oh piece of me, leaving this world, you took it away of me. ${ }^{42}$

Ibn Abī Hajala ${ }^{43}$ also composed maqāmāt, and in his Maqāma al-Kutubiyya, he portrayed the decline of the 14th century's book market in Cairo, the reactions on the part of the elites to the rise of popular literary forms, and the circulation of books. He also provided data on which were the "must read" Andalusi works for achieving an adequate intellectual formation. These are al-'Tqd al-farid by Ibn 'Abd Rabbihi, Qalāid al- 'iqyān by Ibn Khāqān, the Dhakhïra by Ibn Bassām, and Ibn Șāiid al-Andalusī's Kitāb Ṭabaqāt al-Umam.44

Finally, the secretary of the chanceries of Syria and Egypt, Ibn Hijja alHamawi $(767-837 / 1366-1434)$ wrote the Qahwat al-insh $\bar{a}^{3}$, a valuable source for Mamluk literature and history. This epistolary collection includes Ibn Hijja's own letters and documents written by his contemporaries or coming from

\footnotetext{
39 Kilpatrick, Adab i, 175-6; Genre 34-42.

40 See the studies carried out by Papoutsakis, Anthologist's 417-36 and Pomerantz, Maqāmah 179-207.

41 Ibn Abī Ḥajala, Dīwān 29, 75.

42 Ibn Abī Ḥajala, Salwat 82.

43 For the political events of this period, see Irwin, Middle 125-51; Van Steenbergen, Order.

44 Pomerantz, Maqāmah 188-96.
} 
foreign governments to which he responded. One of these letters mentioned the importance and fame of Ibn 'Abd Rabbihi's work, acknowledging it as one of the most valued of its genre. ${ }^{45}$

Later, in the 16th and 17th centuries, authors like al-Maqqarī in his Nafh al-țīb, or Ibn al-'Imād in his Shadharāt al-dhahab, again revealed the Eastern success of the Iqd al-farid. ${ }^{46}$

Further research needs to be carried out in order to detail, for example, which parts of the Iqd enjoyed greater impact, as shown in the summaries that were written on the work. Also, the manuscript transmission of this adab work needs to be studied. The evidence provided here demonstrates how Andalusis' travels to the East in search of knowledge were the channels through which the reception of the Andalusi production took place and that the personalities and skills of those travelers were decisive in determining the success of such production, or lack thereof, regardless of the quality of the work. Al-Ṣahịib b. 'Abbād's dismissive remark on the Iqd as providing nothing new (in fact, it does contain very little Maghrebi materials) and as being a recycling of knowledge of Eastern provenance made sense in a 1oth-century context in which the sources used by Ibn 'Abd Rabbihi (and on which we have the excellent study by Werkmeister) were still available. Three centuries later, the I $q d$ would be appreciated by the Mamluk scholars precisely for such "recycling" of older materials, because by collecting it, Ibn 'Abd Rabbihi not only preserved important previous works but gave them form and meaning.

\section{Bibliography}

\section{Primary Sources}

al-Dabbī, Bughyat al-multamis, 2 vols., ed. al-Abyārī, Cairo 1989.

al-Dhahabī, Siyar a'lam al-nubalä̀, s.e., 1997.

al-Humaydī, Jadhwat al-Muqtabis fì tärīkh 'ulamä’ al-Andalus, ed. 'A. al-Suwayfï, Beirut 1997 .

Ibn al-Abbār, al-Takmila li-kitāb al-Ṣila, ed. I. al-Abyarī, Cairo 1989.

45 See Ibn Hijja al-Ḥamawī, Qahwat 315-9.

46 See al-Maqqarī, Naf̣̣ ii, 118-9, 511; iii, 158-9, 186-94; vi, 22-7, 145-6, 509-13; vii, 49-52, 6973; Ibn al-'Imād, Shadharāt iii, 12-13. 
Ibn 'Abd Rabbihi, al-Iqd al-farīd, 9 vols., ed. M. Qumayha and 'A. al-Tarhinī, Beirut 2006. Ibn Abī Hajala, Dēwān al-Sabāba, ed. M. Zaglūl Sallām, Alexandria 1987.

Ibn Abī Hajalah, Salwat al-hazin fi mawt al-banīn, ed. M. Șāliḥ, Amman 2009.

Ibn Bashkuwāl, Kitab al-Ṣila, 3 vols, ed. I. al-Abyarī, Cairo 1989.

Ibn Bassām, al-Dhakhīra fì maḥ̂̄sin ahl al-jazīra, 4 vols., ed. I. 'Abbās, Beirut 2000.

Ibn al-Faraḍī. Ta’rīkh 'ulamā' al-Andalus, 2 vols., ed. B.'A. Ma'rūf, Tunis 2008.

Ibn Hijja al-Hamawī, Qahwat al-inshā’, ed. R. Pizzili, Beirut 2005 .

Ibn al-Imād, Shadharāt al-dhahab, 9 vols, ed. M.Abd al-Qādir 'Ațā, Beirut 1998.

Ibn al-Kattanī, Kitāb al-Tashbihāt min ash`ār ahl al-Andalus, ed. I. 'Abbās, Beirut 1966.

Ibn Khallikān, Wafayāt al-a'yān wa anbā' abnā’ al-zamān, ed. I. 'Abbās, Beirut 1968

[trans. W. Mac Guckin de Slane, Ibn Khallikan's biographical dictionary].

Ibn Khāqān, Matmaḥ al-anfus wa masrạ̣ al-ta’annus fi mulaḥ ahl al-Andalus, ed. M.

'A. Shawābika, Beirut 1983 .

Ibn Qutayba, A., Kitāb 'Uyūn al-Akhbār, 2 vols., ed. Y.'A Tawīl and M. Qumayha, Beirut 2003.

Ibn Șāiid al-Andalusī, Kitāb Tabaqāt al-Umām, ed. Ḥ. Bū Alawān, Beirut 1985.

Ibn Sa'īd al-Maghribī, al-Mughrib fi ḥulā al-Maghrib, 2 vols., ed. Sh. Ḍayf, Cairo 1953-5. Ibn Kathīr, al-Bidāya wa l-nihāya, 15 vols., ed. Maktabat al-Ma'ārif, Beirut 1991.

al-Maqqarī, Nafṭ al-țīb, 10 vols, ed. M.Q. Ṭawīl and Y.'A. Țawīl, Beirut 1995.

al-Nuwayrī, Nihāyat al-arab fi funūn al-adab, 16 vols., ed. M.M. Qumayḥa, Beirut 2004. al-Qalqashandī, Șubḥ al-a shhā fì șinā́at al-inshā', 14 vols., ed. M. Qundayl al-Baqlī and S.'A. 'Āshūr, Cairo 1985.

al-Ṣafadī, Kitāb al-wāfì bi-l-wafayāt, 29 vols., ed. A. al-Arna'ūṭ and T. Mușțafā, Beirut 2000.

al-Tha'alabī, Yatìmat al-dahr, 5 vols., ed. M.M. Qumayḥa, Beirut 1983.

Yāqūt al-Ḥamawī, Mújam al-udabā’ Kitāb Irhsād al-arīb ilā márifat al-adīb, 7 vols., ed.

I. 'Abbās, Beirut 1993.

\section{Secondary Sources}

Boullata, I., The unique necklace, 3 vols., Reading 2007-12.

Bray, J., 'Abbasid myth and the human act, in P. Kennedy (ed.), On fiction and adab in medieval Arabic literature, Wiesbaden 2005, 1-54.

Brockelmann, C., Ibn 'Abd Rabbih, in $E I^{2}$, iii, 676-7.

Chafic Damaj, A. La introducción de obras orientales en al-Andalus por dos sabios sevillanos de la época almohade, in Miscelánea de Estudios Arabes y Hebraicos 56 (2007), 51-7.

Chalmeta, P., Historiografía Medieval hispano-arábiga, in al-Andalus 37 (1972), 353404.

Cheikh-Moussa, A. Considérations sur la littérature d'Adab. Présence et effets de la voix et autres problems connexes, in al-Qantara 27 (2006), 25-62. 
Dū n-Nūn Taha, A., Importance des voyages scientifiques entre l' Orient et l' Andalus, in Revue de l'Occident musulman et de la Méditerranéé 40 (1985), 39-44.

Franssen, E., What was there in a Mamluk Amïr's library? Evidence from a fifteenthcentury manuscript, in Developing Perspectives in Mamluk History 143 (2017), 311-32.

Fierro, M., La legitimidad del poder en el Islam, in Awraq 15 (1994) 147-84.

Fierro, M., Abd al-Rahman III (Makers of the Muslim World), Southport 2005.

Fierro, M. Pompa y ceremonia en los califatos del Occidente islámico (s. ii/vii-ix/xv), in Cuadernos del Centro de Estudios Medievales y Renacentistas 7 (2009), 125-52.

Fierro, M., El saber enciclopédico en el mundo islámico, in A. Alvar Ezquerra, (coor.), Las Enciclopedias en España antes de "l'Encyclopédie," Madrid 2009, 83-104.

Fierro, M., Abderramán III y el califato omeya de Córdoba, San Sebastián 2011.

Fromherz, A., Ibn Khaldūn, Ibn al-Khațīb and their milieu: A community of letters in the fourteenth-century Mediterranean, in Medieval encounters 20 4/5 (2014), 288305 .

García Gómez, E. (trans.), Andalucía contra Berbería, Barcelona 1976.

Ghersetti, A. (ed.), al-Suyuti, a polymath of the Mamlukperiod:Proceedings of the themed day of the first conference of Mamlük studies (I HC 138), Leiden and Boston 2016.

Haarmann, U., Mamluk studies: A western perspective, in Arab journal for the humanities 13/51 (1995), 329-47.

Haremska, J., Ibn 'Abd Rabbihi, Abū 'Umar, in J. Lirola Delgadoand J.M. Puerta Vílchez (eds.), Biblioteca de al-Andalus, i, Almeria 2012, 620-9.

Hirschler, K., Medieval Damascus: Plurality and diversity in an Arabic library. The Ashrafiya Library Catalogue, Edinburgh 2016.

Homerin, Th.E., Reflections on Arabic poetry in the Mamluk age, in MSR 1 (1997), 63-85.

Ibn Sharīfa, M., Ibn 'Abd Rabbihi al-Hafı̀d: Fușūl min sīra mansīya, Beirut 1992.

Irwin, R., Mamluk literature, in MSR 7 (2003), 1-29.

Irwin, R., The Middle East in the middle ages: The early Mamluk Sultanate, 1250-1382, Illinois 1986.

Jabbūr, J.S., Ibn 'Abd Rabbih wa Iqduhu, Beirut 1933.

Kilpatrick, H., A genre in classical Arabic literature: The Adab encyclopedia, R. Hillenbrand (ed.), Union Européenne des Arabisants et Islamisants 1oth Congress, Edinburgh 1982, 34-42.

Kilpatrick, H., Classical Arabic prose literature: A researchers' sketch map, in JAL 23/1 (1992), 2-26.

Kilpatrick, H., Beyond decadence: Dos and don'ts in studying Mamluk and Ottoman literature, in Middle Eastern literatures 12 (2009), 71-80.

Kilpatrick, H., Adab, $E I^{2}$, i, 175-6.

Lévi-Provençal, E., and E. García Gómez (eds.), España Musulmana (711-1031) La conquista el emirato, el califato, Historia de España de Ramón Menéndez Pidal, iv, Madrid 1996. 
López, D., ¿Autor, creador, re-creador ...? Técnicas de composición y originalidad en la literatura de adab, in Miscelánea de Estudios Árabes y Hebraicos, Sección ÁrabeIslam 66 (2017), 169-93.

Marín, M., La transmisión del saber en Al-Andalus (hasta 30o/912), in al-Qantara 8 (1987), 87-108.

Martínez-Gros, G., L'idéologie omeyyade: La construction de la légitimité du califat de Cordoue $\left(X^{e}-X I^{e} s\right)$, Madrid 1992.

Molina, L., The reception of Ibn Hazm in Arabic chronicles, in C. Adang, M. Fierro and S. Schmidtke (eds.), Ibn Hazm of Cordoba, the life and works of a controversial thinker, Leiden 2013.

Monroe, J.T., The historical Arjūza of Ibn 'Abd Rabbih: A tenth-century Hispano-Arabic epic poem, in JAOS 91 (1971), 67-95.

Muhanna, E., Encyclopaedism in the Mamluk period: The composition of Shihāb alDīn al-Nuwayrī's (D. 1333) Nihāyat al-Arab fı̈ Funūn al-Adab, PhD diss., Harvard University 2012.

Muhanna, E., The world in a book, al-Nuwayri and the Islamic encyclopedic tradition, Princeton 2017.

Orfali, B., The anthologist's art: Abū Manșūr al-Tha'ālibī and his Yatīmat al-dahr, Leiden and Boston 2016.

Orfali, B., The sources of al-Tha'ālibī in Yatìmat al-dahr and Tatimmat al-Yatīma, in Middle Eastern literatures 16 (2013), 1-47.

Orfali, B., The works of Abū Manșūr al-Tha'ālibī (350-429/961-1039), in JAL 40/3 (2009), $273-318$.

Orfali, B., A sketch map of Arabic poetry anthologies up to the fall of Baghdad, in $J A L$ 43/1 (2012), 29-59.

Papoutsakis, N., The anthologist's agenda and concerns in Ibn Abi Hagalah's Magnātis ad-durr an-nafis, in N. Papoutsakis and S. von Hees (eds.), The sultan's anthologist: Ibn Abī Hağalah and his work, Baden-Baden 2017, 417-36.

Peña Martín, S., and M. Vega Martín, El ideal de claridad o los dos fines del Adab según Ibn al-Sīd, in al-Qantara 25/2 (2004), 464-502.

Pomerantz, M., A Maqāmah on the book market of Cairo in the 8th /14th century: The "Return of the stranger" of Ibn Abi Hağalah (d. 776/1375), in N. Papoutsakis and S. von Hees (eds.), The sultan's anthologist:Ibn AbīHağalah and his work, Baden-Baden 2017, 179-207.

Pouzet, L., Maghrébins a Damas au VII ${ }^{\mathrm{e}} / \mathrm{XIII}$ siècle, in BEO 28 (1975), 167-99.

Puerta Vílchez, J.M., and A. Rodríguez Figueroa, Ibn 'Abd Rabbihi al-Hafĩd, in J. Lirola Delgado and J.M. Puerta Vílchez (eds.), Biblioteca de al-Andalus, i, Almeria 2012, 6o9-19.

Ramírez del Río, J., La Orientalización de al-Andalus: Los días de los árabes en la Península Ibérica, Sevilla 2002. 
Sadan, J. Ornate manual sor practical Adab? Some reflections on a unique work by an anonymous author of the 1oth century CE, in al-Qantara 25/2 (2004), 339-55.

Soravia, B., Ibn Qutayba en al-Andalus. La préface à l'adab al-Kātib dans le commentaire d' Ibn al-Sīd al-Batalyawsī, in al-Qantara 25/2 (2004), 539-65.

Toral-Niehoff, I., The "Book on the pearl on the ruler" in The unique necklace by Ibn 'Abd Rabbih, Preliminary remarks, in R. Forster and N. Yavari (eds.), Globalmedieval: Mirrors for princes reconsidered, Cambridge 2015, 134-51.

Toral-Niehoff, I., History in adab context: "The book on caliphal histories" by Ibn 'Abd Rabbih (246/86o-328/940), in Journal of Abbasid studies 2 (2015), 61-85.

Van Steenbergen, J., Order out of chaos: Patronage, conflict, and Mamluk socio-political culture, 1341-82, Leiden 2006.

Van Steenbergen, J., "Mamlukisation" between social theory and social practice: An essay on reflexivity, state formation, and the late medieval sultanate of Cairo, in ASK Working Paper 22 (2015), 1-44.

Veglison, J., El collar único de Ibn Abd Rabbihi, Madrid 2011.

Werkmeister, W., Quellenuntersuchungen zum Kitāb al-Iqd al-farìd des Andalusiers Ibn 'Abdrabbih (246/86o-328/940), Berlin 1983. 